\title{
Singapore, A Growing Economic Titan from South East Asia
}

\author{
Ignatius Hubert Tantra \\ Mahasiswa Ilmu Hubungan Internasional, Fakultas Ilmu Sosial dan Ilmu Politik \\ Universitas Padjadjaran
}

\begin{abstract}
Abstrak
Singapore has one of the fastest economic development pace throughout South East Asia. Despite the fact that by land mass, it is not the biggest or the most fertile country. By demographic factor, it is not the most populated nor the most culturally diverse country. It also didn't have the natural resources that its neighboring countries boasted as their main commodity. Yet, Singapore is a country with one of the most efficient implementation of living space, land usage, and education programme in the world. Because of its greatness, Singapore can be put in the same class with the others developed countries in the world. This is despite all the handicap that this country has, through the thick and thin of its history. The author believes that these successes can be atributted mostly to the efficient leadership of Singapore as a nation state in the international system, and that these successes can be adapted throughout Asia, and the world as a whole. This essay was made exactly to achieve this successful impact on ASEAN's countries economics. In this writing, the author will examine what makes Singapore such a great economic titan, and how it can turn its unlikely position into a flourishing market economy and becoming a model for other developing countries to replicate, with institutional leadership. All of these, for the purpose of learning, and in the bid of rejuvenating economic vigor that most Asian countries and developing countries needed to keep up and even compete with more prominent countries in the international political system of the world.
\end{abstract}

Keywords : ASEAN economic development, Bargainer surplus, Economic power, Entrepreneurial leadership, Institutional bargaining, Intellectual leadership

Pada tahun 2017, tingkat perekonomian Singapura meningkat dari 2.4\% pada tahun 2016 menjadi 3.6\%. Dengan GDP nominal meningkat dari 427.9 miliar USD menjadi 447.3 miliar USD. Hal ini bersamaan juga dengan meningkatnya berbagai sektor ekonomi Singapura lainnya seperti tingkat pekerja, tingkat ekspor, Budget pengeluaran pemerintah, dll. (Trading Economics, 2018) dimana peningkatan terbesar terjadi di sektor manufaktur, akomodasi dan layanan tata boga (Government of Singapore, 2018). Hal ini menunjukkan perkembangan pesat, yang mungkin tidak dirasakan oleh sebagian besar negara-negara di Asia Tenggara (International Monetary Fund, 2017). 
Singapura merupakan salah satu negara yang memiliki kualitas pendidikan masyarakat terbaik di Asia Tenggara. Hal ini dapat dilihat dari semakin meningkatnya jumlah anak-anak yang masuk ke sekolah / menempuh pendidikan dari tahun ke tahun, di dukung dengan meningkatnya alokasi anggaran pemerintah dalam sektor pendidikan setiap tahunnya semenjak tahun 1981 (Data.gov.sg, 2018). Indikator tingkat melek huruf yang menempatkan negara Singapura dalam urutan ke 41 di seluruh dunia dengan $94.5 \%$ dari seluruh masyarakat Singapura sudah dapat menguasasi kemampuan membaca dan menulis (NationMaster, 2018).

Kedua hal ini menunjukan prioritas yang jelas di dalam rencana pembangunan pemerintah Singapura, yaitu dari segi infrastruktur dan pengembangan sumber daya manusia. Ketimpangan yang jelas antara Singapura dan negara-negara Asia Tenggara, bahwa model kepemimpinan pemerintah Singapura telah berhasil di dalam menggerakan perkembangan negara Singapura, terutama dalam sektor ekonomi dan pendidikan ke arah positif (Tan A. H., 1986).

Kepemimpinan seringkali bukan menjadi kajian utama di dalam menilai keberhasilan ataupun kegagalan suatu pemerintahan. Namun, dalam jurnalnya Oran R. Young mendebat bahwa, kepemimpinan adalah faktor krusial penentu keberhasilan proses kerjasama internasional, dan juga proses berjalannya suatu institusi pemerintahan domestik (Young, 1991). Young menilai bahwa kepemimpinan adalah fenomena yang kompleks dan kurang di mengerti, namun penting untuk dipelajari demi tercapainya tujuan nasional dan harmonisasi kepentingan bersama di dalam sistem internasional.

Di dalam penjelasannya Young menjelaskan mengenai sistem institutional bargaining didalam penyusunan kerangka kerja internasional. Young disini menunjukkan dinamika masyarakat internasional di dalam menyelesaikan masalah bersama dan bagaimana hambatan, peran serta, pengaruh dari kepemimpinan di dalam sistem institutional bargaining ini. Meskipun teori young lebih fokus kepada pencapaian konsensus dan kesepakatan bersama di level internasional, tetapi pola institutional bargaining juga terdapat di dalam politik domestik, terutama di dalam

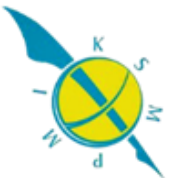


mencapai suatu kebijakan nasional yang memengaruhi kehidupan masyarakat secara umum, seperti subsidi bbm, dana bantuan pendidikan, dsb. Dalam hal ini dapat dilihat pengaruh kepemimpinan dalam bidang pencapaian kesepakatan bersama, seperti yang terdapat di tingkat internasional.

Kemudian Young menjelaskan mengenai hakikat kepemimpinan di dalam hubungan internasional. Young melihat ada beberapa masalah mengenai sudut pandang masyarakat terhadap pemerintah, yang menurutnya kurang merepresentasikan peran sesungguhnya yang dapat dibawakan oleh kepemimpinan bagi suatu negara, dan secara lebih luas di dalam hubungan internasional. Beliau melihat bahwa peran kepemimpinan bukan di dalam keberhasilan terbentuknya suatu perjanjian, tetapi lebih kepada bagaimana peran pemimpin di dalam proses negosiasi dan penyusunan kebijakan itu sendiri. Salah satu permasalahan utama mengenai kepemimpinan rakyat, adalah masyarakat terlalu terfokus kepada faktor dominasi dan pengaruh dari suatu pemerintahan dibandingkan kemampuan kemampuan pemimpin terkait dalam konteks individu itu sendiri di dalam mencapai kesepakatan, dan kerjasama (Kindleberger, 1981). Young menekankan bahwa pemimpin adalah "individu" meskipun ia merepresentasikan kepentingan banyak orang, maka setiap kajian terhadap suatu kepemimpinan menggunakan level of analysis dari sudut pandang individu serta perilakunya di dalam penentuan dan penyusunan suatu kebijakan yang akan mempengaruhi secara kolektif baik masyarakat negara nya atau komunitas internasional (Riddell-Dixon, 1997). Young kemudian lebih jauh membagi tipe kepemimpinan sesuai teorinya menjadi 3 jenis, yaitu Structural Leadership, Entrepeneurial Leadership, dan Intellectual Leadership.

Structural Leadership adalah tipe kepemimpinan yang mampu mengubah kemampuan material, sumber daya, atau kekuatan fisik sebuah negara demi melancarkan kepentingan negaranya di dalam institutional bargaining. Di dalam masyarakat internasional maupun domestik terdapat ketidakseimbangan, dimana ketidakseimbangan ini menyebabkan ketidakpastian antara pihak yang bernegosiasi

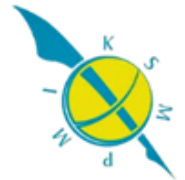


di mana satu sama lain tidak dapat menebak kapabilitas pihak lainnya (Young, 1991). Seorang pemimpin struktural dapat menggunakan ini demi kepentingannya dalam dua cara. Yang pertama adalah secara pasif menggunakan kelebihan yang dimiliki negaranya untuk menekan pihak lain yang lebih membutuhkan tercapainya kesepakatan secara cepat, yaitu dengan menunggu hingga pihak lain terpaksa untuk melakukan perjanjian yang tidak sepenuhnya mereka setujui tetapi harus dicapai sesegera mungkin. Cara kedua adalah secara aktif dan strategis menggunakan kelebihan dan kekuatan guna mewujudkan keputusan yang merepresentasikan kepentingan pihaknya; yaitu dengan secara tepat melaksanakan ancaman dan janji akan insentif tertentu kepada pihak lain di dalam institutional bargaining.

Entrepeneurial Leadership membahas mengenai “bargainer's surplus”, yaitu keuntungan yang dapat dicapai oleh kedua pihak jika berhasil mencapai suatu kesepakatan bersama, terhadap posisi masing-masing pihak saat ini. Peran dari pemimpin Entrepeneurial adalah untuk membimbing proses negosiasi guna mencapai kata sepakat, terutama dengan mengedepankan kepentingan pihak yang di representasikan oleh pemimpin Entrepeneurial itu sendiri. Secara garis besar, pihak pemimpin Entrepeneurial dapat dijabarkan sebagai berikut : (1) Penetap agenda, yaitu membentuk bagaimana cara suatu isu dibawa ke dalam konsiderasi masyarakat internasional dan domestik. (2) memopulerkan suatu isu, dan menarik perhatian masyarakat kepada pentingnya penyelesaian isu tersebut. (3) menciptakan penyelesaian masalah yang inovatif untuk menghindari terjadinya hambatan terhadap tercapainya kesepakatan mengenai suatu isu. (4) menjadi narahubung di dalam mempertemukan kepentingan pihak-pihak yang berbeda, dan menawarkan opsi-opsi lain yang mungkin disepakati oleh mereka (Young, 1991).

Tipologi kepemimpinan terakhir yang dipaparkan oleh Oran R. Young adalah Intellectual Leadership, dan tipe kepemimpinan inilah yang menurut penulis paling dekat menyerupai model kepemimpinan di Singapura. Berbeda dengan kepemimpinan Entrepeneurial yang menggunakan kemampuan nalar untuk menggiring terbentuknya kesepakatan antara pihak-pihak yang bernegosiasi, 
kepemimpinan Intellectual berusaha menciptakan pemahaman dasar dalam bentuk kerangka pemikiran yang bisa disetujui bersama antara pihak-pihak yang bernegosiasi untuk menyelesaikan suatu masalah bersama (Young, 1991). Untuk dapat menyelesaikan suatu isu, terkadang belum diketemukan kerangka pemikiran yang sama diantara pihak-pihak yang bernegosiasi mengenai konsepsi masalah yang dihadapi bersama tersebut. Tugas dari seorang pemimpin Intellectual adalah untuk mengartikulasikan pemikiran-pemikiran, kepentingan, dan pendapat yang berbeda ini ke dalam suatu teori dan pemahaman yang koheren bagi semua peserta negosiasi, lalu menjadikan pemahaman bersama tersebut sebagai dasar pembentukan kebijakan yang saling menguntungkan bagi pihak-pihak dalam persetujuan tersebut.

Berdasarkan penjelasan teori Oran R. Young mengenai peran kepemimpinan di dalam masyarakat internasional, penulis dapat melihat pararel antara kepemimipinan di Singapura dan pada tipologi kepemimpinan Entrepreneurial dan Intellectual. Yaitu, dimana Singapura tidak memiliki kemampuan sumber daya sebesar negara lain di dalam model institutional bargaining, tetapi Singapura lebih banyak menggunakan kemampuan diplomasi, negosiasi, dan kemampuan ekonomi di dalam kebijakan politiknya, baik politik luar negeri maupun domestik. Namun, hal ini bukan berarti bahwa di dalam kebijakannya, pemerintah Singapura tidak lepas dari kebutuhan dan insentif pembangunan fisik, hanya saja bahwa pemerintah Singapura lebih terfokus kepada segi pendidikan dan kewirausahaan dibandingkan struktural secara garis besar (Choy, 1985).

Dapat kita lihat pasar Singapura saat ini berkembang dengan pesat dibanding dengan negara-negara ASEAN lainnya. Hal ini dikarenakan Singapura sendiri telah mengadopsi sistem pasar terbuka yang sangat mengakomodasi kebebasan individu untuk mengembangkan modal dan mencari keuntungan sebesar-besarnya (Lim, 1983). Kebijakan pemerintah Singapura terkait pasar juga berhasil menciptakan iklim yang bersahabat bagi investor asing, sehingga tingkat Foreign Direct Investment (FDI) Singapura, menduduki peringkat ke-8 tertinggi di dunia, dan 
nomor 3 di Asia setelah China dan Hongkong (Ming, 2018), dengan perkiraan FDI sebesar \$58 Milyar, tersebar di berbagai sektor perekonomian yang berbeda (Dezan Shira and Associates, 2017). Selain investasi, penulis juga melihat bahwa dari segi ekonomi, GDP Singapura dapat disejajarkan dengan GDP negara-negara maju lain di dunia (Trading Economics, 2018), meskipun seperti yang telah penulis jelaskan sebelumnya pemerintahan Singapura tidak memiliki wilayah, sumber daya alam, ataupun sumber daya manusia sebanyak yang dimiliki negara ASEAN lainnya. Hal ini menunjukkan bahwa pemerintah Singapura mampu mengoptimalkan kekuatan yang dimilikinya secara efektif dan sebagai dampaknya dapat meningkatkan produktvitas negaranya untuk mencapai efisiensi perekonomian pada tingkat yang sebanding dengan negara-negara maju di dunia. Hal ini sangat menunjukkan adanya ciri khas Entrepreneurial Leadership dan Intellectual Leadership di dalam perekonomian Singapura

Lebih jauh lagi, keberhasilan ekonomi ini memiliki imbas yang besar kepada segi pendidikan dan kesejahteraan penduduk Singapura secara khusus, dan bahkan kesejahteraan perekonomian ASEAN secara umum. Tingkat buta huruf di Singapura sangatlah minim yakni hanya sekitar 3,2\% dengan tren peningkatan positif setiap tahunnya (Knoema, 2018), hal ini menunjukkan adanya kepedulian tinggi dari pemerintah Singapura untuk meningkatkan pendidikan masyarakatnya. Salah satu sektor unggulan Singapura lainnya adalah kependudukan, perencanaan keluarga, dan optimalisasi penggunaan lahan untuk kehidupan masyarakat yang sangat baik jika dibandingkan dengan negara ASEAN lainnya (Wan Fook Kee, 1975). Singapura juga memiliki salah satu tingkat partisipasi pendidikan yang tertinggi di ASEAN (Unesco Institute for Statistics, 2018), didukung dengan tingginya tingkat masyarakat yang bersekolah di sekolah dasar (The World Bank, 2018), dan juga kesadaran yang besar di dalam masyarakat untuk menempuh pendidikan tinggi (Ministry of Education Singapore, 2017). Hal ini menunjukkan respon positif masyarakat Singapura terhadap fokus pemerintahan Singapura terutama mengenai pendidikan.

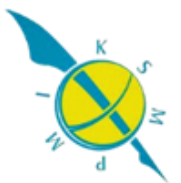


Tapi apakah dampak yang dirasakan penduduk Singapura hanya dari segi mental dan psikis saja? Ternyata dampak tipologi kepemimpinan dan sebagai efek langsungnya; kebijakan negara juga memiliki pengaruh di dalam perkembangan fisik negara, infrastruktur, pembangunan, bahkan kesehatan dan kesejahteraan hidup masyarakat Singapura. Singapura mengalami tingkat pertumbuhan fisik yang pesat, bahkan pemerintah Singapura sudah mencanangkan program pembangunan infrastruktur yang lebih ramah lingkungan untuk masa depan (Urban Redevelopment Authority, n.d.). Singapura juga salah satu negara ASEAN dengan tingkat harapan hidup tertinggi, dengan usia harapan hidup total sebesar 83,1 tahun (Global Health Observatory, 2018) menjadikannya negara dengan usia harapan hidup ketiga tertinggi di dunia, dengan usia harapan hidup wanita sebesar 86.1 dan pria sebesar 80.1, hanya berada dibawah negara maju seperti Jepang dan Swiss (Mediacorp News Group, 2017). Selain itu, tingkat kesehatan publik Singapura juga bisa dikatakan baik (Ministry of Health Singapore, 2018), dengan harga layanan kesehatan yang sangat bersaing dibandingkan di negara lain, dan efisien secara internasional (Bloomberg Visual Data, 2014). Faktor-faktor ini tentu kedepannya akan dapat memberikan insentif untuk lebih banyak terjadinya perdagangan dan masuknya investasi asing, serta meningkatkan produktivitas domestik Singapura sendiri dan lebih jauh lagi mengukuhkan posisi Singapura sebagai salah satu kekuatan ekonomi dunia (Mahizhnan, 1994) .

Hal ini tidak bisa lepas atributnya dari model kepemimpinan Entrepreneurial Leadership yang berusaha untuk mengembangkan nilai-nilai non konvensional (infrastruktur, pembangunan fisik, eksploitasi SDA). Dan juga Intellectual Leadership yang mengedepankan revolusi mental dan pembangunan kerangka pemikiran masyarakat Singapura lewat pendidikan. Mungkin tidak ada korelasi secara langsung yang jelas terlihat antara tipologi kepemimpinan tersebut dengan kesuksesan dan meningkatnya kekuatan Singapura di berbagai bidang. Namun kita juga dapat melihat kebalikannya, bahwa di dalam negara dimana tidak terdapat kedua tipologi kepemimpinan tersebut tidak terdapat peningkatan tinggi di dalam

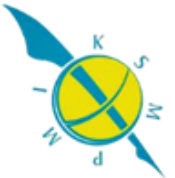


indikator-indikator yang jelas mengenai ekonomi negaranya; seperti GDP, pembangunan fisik, tingkat melek huruf, dan lain sebagainya seperti yang telah penulis paparkan mengenai Singapura di bagian sebelumnya. Maka dapat diperhatikan bahwa sesungguhnya pengaruh kepemimpinan ternyata merupakan faktor yang kurang diperhatikan, namun sangat besar pengaruhnya di dalam mengukuhkan kekuatan, pengaruh, dan posisi suatu negara dalam sistem internasional. Bahkan pengaruhnya dapat dikatakan melebihi ketersediaan SDA, teknologi, ataupun kemampuan SDM dari negara itu sendiri, meskipun faktor-faktor ini juga mempengaruhi dan dapat membantu mempercepat transisi dari negara berkembang menjadi negara maju, dan bahkan negara economic titan seperti dalam kasus Singapura.

Negara adalah institusi yang bergerak atas dasar dan mewakili kepentingan dari masyarakat yang menjadi konstituen negara itu sendiri. Disini penulis memfokuskan bahwa di dalam institusi negara tersebut, ternyata faktor kepemimpinan memainkan peran yang sangat penting di dalam memajukan ekonomi, sosial, kesejahteraan, dan fisik suatu negara (Riddell-Dixon, 1997). Dan bahwa berdasarkan tiga tipologi kepemimpinan Oran R. Young, ternyata setiap negara mempunyai tipologi kepemimpinan yang berbeda, berdasarkan faktor sosial kultural, sumber daya, dan budaya yang berlaku di dalam negara tersebut. Oleh sebab itu beberapa negara mempunyai tipologi kepemimpinan Structural (seperti AS, Cina, Rusia), sedangkan yang lain mungkin memiliki tipologi kepemimpinan Entrepreneurial atau intelektual karena minimnya sumber daya yang tersedia bagi negara tersebut, sehingga harus menggunakan cara lain di dalam mencapai kepentingannya.

Tipologi ini juga berhubungan langsung dampaknya terhadap konstruksi dan pandangan umum masyarakat suatu negara mengenai, keadaan sosial di dalam masyarakatnya dan bagaimana tindakan yang harus mereka ambil dalam menghadapinya. Di bawah kepemimpinan structural, mungkin dengan alur kebjiakan yang pemimpin negara tersebut ambil akan membawa masyarakat kepada

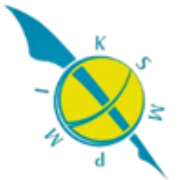


konstruksi yang lebih self centered dan berusaha mencari kepentingan pribadi di dalam masyarakat. Sedangkan di dalam entrepreneurial leadership mungkin akan lebih banyak usaha untuk merangkul semua golongan dan mencapai kesejahteraan yang menyeluruh. Contoh ini lebih jauh mengukuhkan peranan kepemimpinan di dalam memajukan suatu negara, dan contohnya dapat kita lihat juga di dalam kepemimpinan Singapura, yang menurut penulis telah berhasil menerapkan tipologi kepemimpinan yang sesuai dengan profil dan demografi masyarakatnya, dan sukses juga untuk mengonstruksi masyarakatnya ke dalam kerangka berpikir pasar bebas yang mengedepankan nilai-nilai pendidikan dan kesejahteraan (Meng, 1977). Dampak dari kepemimpinan ini sendiri, berdasarkan bukti dan statistik yang telah penulis paparkan sebelumnya, telah berhasil menghantarkan Singapura untuk menyandang gelar sebagai Economic Titan di ASEAN dan bahkan di dunia.

Mengerti dan memahami mengenai tipologi kepemimpinan seperti apa yang suatu negara miliki, akan sangat penting untuk melancarkan strategi pelaksanaan tata pembangunan fisik dan sosial, kebijakan domestik dan luar negeri, dan secara umum garis besar perkembangan negara itu sendiri. Hal ini pun berlaku bagi Singapura. Meskipun Singapura sedang mengalami perkembangan dan pertumbuhan yang sangat pesat di dalam berbagai bidang, terutama ekonomi, Singapura sebagai negara tetap memiliki kewajiban-kewajiban tertentu yang harus dipenuhi menyangkut kebutuhan warga negaranya dan juga sebagai bagian dari sistem internasional dan regional di ASEAN (Bhaskaran, 2014), juga bidang-bidang lain yang mungkin bukan merupakan perhatian utama, namun penting juga untuk diberlakukan oleh Singapura, seperti diplomasi, hubungan dengan negara luar, dan bahkan pertahanan militer (Tan A. T., 1999). Hal ini dilakukan sebagai respon Singapura terhadap faktor-faktor eksternal yang dapat mempengaruhi politik internal negaranya, dan sebagai jawaban tantangan jaman akan relevansi negara Singapura itu sendiri (Singh, 2008).

Maka menurut penulis, jawaban dan tindakan yang harus diambil oleh Singapura sebagai negara agar kedepannya dapat meneruskan momentum baik ini, 
yang mungkin dapat juga diterapkan oleh negara ASEAN lainnya untuk berkembang adalah untuk mempelajari dan melakukan riset lebih jauh mengenai kapabilitas, karakteristik, dan batasan-batasan yang dimiliki negara tersebut baik secara politik, ekonomi, dan sosial-budaya, lalu mengimplementasikan penemuan ini kedalam tipologi kepemimpinan yang sesuai, dan menerapkan tipologi kepemimpinan ini untuk memajukan kepentingan negara di dalam berbagai dimensi nya. Karena suatu negara, terutama sebuah Economic Titan akan membutuhkan saling kerjasama, kepercayaan, dan transparansi yang kuat antar pemerintah dengan rakyatnya, dan antar institusi pemerintah itu sendiri. Hal tersebut dilakukan agar Singapura senantiasa mampu membangun dan mempertahankan sistem pemerintahan, tipologi kepemimpinan dan ekonomi pasar yang lebih kuat untuk menghadapi dominasi negara-negara dengan perekonomian yang lebih prominen di dalam sistem internasional.

\section{Daftar Pustaka}

Bhaskaran, M. (2014). Challenges Facing The Singapore Economy. Southeast Asian Affairs, 290-302.

Bloomberg Visual Data. (2014, September 18). Where Do You Get the Most for Your Health Care Dollar? Retrieved from Bloomberg: https://www.bloomberg.com/graphics/infographics/most-efficient-health-carearound-the-world.html

Choy, C. L. (1985). Development Management in Singapore: Institutional Leadership in Development. Southeast Asian Affairs, 306-316.

Data.gov.sg. (2018, April 14). Education at a glance. Retrieved from Data.gov.sg: https://data.gov.sg/group/education

Dezan Shira and Associates. (2017). Singapore's FDI Outlook for 2017: Recent Trends. Dezan Shira and Associates. Retrieved from https://leaglobal.com/thought_leadership/Singapore\%202017\%20FDI\%20Outl ook.pdf

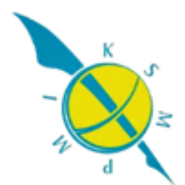


Global Health Observatory. (2018, May 05). Countries : Singapore. Retrieved from

World Health Organization: http://www.who.int/countries/sgp/en/

Government of Singapore. (2018, February 2018). GDP : Economic Perfomance.

Retrieved from Department of Statistics Singapore:

https://www.singstat.gov.sg/statistics/visualising-data/storyboards/gdp

International Monetary Fund. (2017, August). Report for Selected Countries and

Subjects. Retrieved from International Monetary Fund:

http://www.imf.org/external/pubs/ft/weo/2017/02/weodata/weorept.aspx?sy=2

017\&ey=2017\&scsm=1\&ssd=1\&sort=country\&ds=.\&br=1\&pr1.x=93\&pr1.y= $8 \& \mathrm{c}=548 \% 2 \mathrm{C} 518 \% 2 \mathrm{C} 516 \% 2 \mathrm{C} 522 \% 2 \mathrm{C} 566 \% 2 \mathrm{C} 576 \% 2 \mathrm{C} 578 \% 2 \mathrm{C} 536 \% 2 \mathrm{C} 544$ $\% 2 \mathrm{C} 582 \& \mathrm{~s}=\mathrm{NGDPD} \% 2 \mathrm{CPPPGDP} \% 2 \mathrm{CNGDPDPC} \% 2 \mathrm{CPPPPC} \% 2 \mathrm{CLP} \& \mathrm{grp}=$ $0 \& a=$

Kindleberger, C. P. (1981). Dominance and Leadership in the International Economy: Exploitation, Public Goods, andFree Rides. International Studies Quarterly, 242-254.

Knoema. (2018, May 5). Singapore - Adult (15+) literacy rate. Retrieved from World Data Atlas :

https://knoema.com/atlas/Singapore/topics/Education/Literacy/Adult-literacyrate

Lim, L. Y. (1983). Singapore's Success: The Myth of the Free Market Economy. Asian Survey, 752-764.

Mahizhnan, A. (1994). Developing Singapore's External Economy. Southeast Asian Affairs, 285-301.

Mediacorp News Group. (2017, May 18). Singapore 3rd in the world for life expectancy: WHO report . Retrieved from Today Online : Singapore: https://www.todayonline.com/singapore/singapore-3rd-world-life-expectancywho-report

Meng, C. W. (1977). The Singapore Economy: Past Performance, Current Structure and Future Growth Prospects. Southeast Asian Affairs, 220-229.

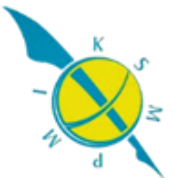


Ming, C. P. (2018, January 29). Singapore, HK biggest Asia recipients of FDI after

China in 2017: UNCTAD. Retrieved from The Business Times:

http://www.businesstimes.com.sg/government-economy/singapore-hk-biggestasia-recipients-of-fdi-after-china-in-2017-unctad

Ministry of Education Singapore. (2017). Education Statistics Digest. Ministry of Education Singapore.

Ministry of Health Singapore. (2018, May 5). Singapore Health Facts. Retrieved from Ministry of Health Singapore : Statistics:

https://www.moh.gov.sg/content/moh_web/home/statistics/Health_Facts_Singa pore.html

NationMaster. (2018, April 14). Singapore Education Stats. Retrieved from

NationMaster: http://www.nationmaster.com/country-

info/profiles/Singapore/Education

Riddell-Dixon, E. (1997). Individual Leadership and Structural Power. Canadian Journal of Political Science, 257-283.

Singh, B. (2008). Singapore: Success at Home, Challenges from Abroad. Southeast Asian Affairs, 315-330.

Tan, A. H. (1986). SINGAPORE'S ECONOMY: Growth and Structural Change. Southeast Asian Affairs, utheast Asian Affairs, 273-295.

Tan, A. T. (1999). Singapore's Defence: Capabilities, Trends, and Implications. Contemporary Southeast Asia, 451-474.

The World Bank. (2018, May 05). School enrollment, primary (\% net). Retrieved from The World Bank: https://data.worldbank.org/indicator/SE.PRM.NENR

Trading Economics. (2018, May 5). Singapore GDP. Retrieved from Trading Economics: https://tradingeconomics.com/singapore/gdp

Unesco Institute for Statistics. (2018, May 05). Education and Literacy : Singapore. Retrieved from UNESCO Institute of Statistics: http://uis.unesco.org/country/SG

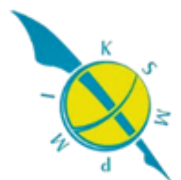


ISSN 0216-5031

$\mathrm{H}$ a I a $\mathrm{m}$ a $\mathrm{n} \mid \mathbf{5 4}$

Urban Redevelopment Authority. (n.d.). Designing our City : Planning for a

Sustainable Singapore. Urban Redevelopment Authority.

Wan Fook Kee, M. L. (1975). Singapore. Studies in Family Planning, 236-238.

Young, O. R. (1991). Political Leadership and Regime Formation: On the

Development of Institutions in International Society. International

Organization. 